\title{
Analisis Morfometri dan Faktor Kondisi pada Cumi-Cumi Photololigo chinensis dan Photololigo duvaucelii yang Didaratkan di Beberapa TPI Pantai Utara Jawa Tengah
}

\author{
Mulkan Nuzapril, Niniek Widyorini, Norma Afiati ${ }^{1}$
}

Program Studi Manajemen Sumberdaya Perairan, Jurusan Perikanan

Fakultas Perikanan dan Ilmu Kelautan, Universitas Diponegoro

\begin{abstract}
ABSTRAK
Salah satu hasil laut yang memiliki nilai ekonomis tinggi setelah ikan dan udang adalah cumi-cumi. Cumi-cumi merupakan salah satu jenis sumberdaya perikanan yang berperan nyata dalam sektor perikanan laut dan banyak dikonsumsi oleh masyarakat. Pemanfaatan sumberdaya cumi-cumi melalui kegiatan penangkapan sudah saatnya disertai dengan upaya pengaturan penangkapan. Upaya ini dapat memperbaiki kerusakan sumberdaya cumi-cumi, karena stok dapat diperkaya untuk memperbaiki dan mempertahankan kelestarian sumberdaya cumi-cumi. Studi mengenai morfometri dari cumi-cumi sangat diperlukan guna selektivitas ukuran bagi kegiatan penangkapan. Selektivitas alat tangkap sangat penting dilakukan untuk menghindari terjadinya overfishing. Tujuan penelitian ini adalah mengetahui karakteristik morfometri dan faktor kondisi dari cumi-cumi P.chinensis dan P. duvaucelii yang didaratkan di TPI sekitar Pantai Utara Jawa Tengah. Metode yang digunakan pada penelitian ini adalah metode deskriptif yang dalam pelaksanaannya dilakukan melalui teknik survei yaitu melakukan kegiatan pengamatan secara langsung dilapangan dengan bertanya terhadap nelayan sebagai data primer dan pengambilan sampel menggunakan metode random sampling yaitu bahwa semua anggota populasi mempunyai peluang yang sama untuk dimasukkan sebagai anggota sampel. Hasil penelitian ini adalah mengidentifikasi 2 jenis cumi-cumi yaitu P.chinensis dan $P$. duvaucelii. Ukuran yang mendominasi untuk $P$. duvaucelii yaitu berkisar antara $25-40 \mathrm{~mm}$ dan $P$. chinensis yaitu antara ukuran $55-70 \mathrm{~mm}$. Hubungan panjang berat $P$.chinensis dan $P$. duvaucelii mempunyai persamaan $\mathrm{W}=0,0024 \mathrm{~L}^{2,055}$ dan $\mathrm{W}=0,00129 \mathrm{~L}^{2,213}$. Karakteristik alometri pada cumi-cumi P.chinensis dan P.duvaucelii mempunyai sifat pertumbuhan alometrik positif, alometrik negatif dan isometrik. Nilai faktor kondisi dari P.chinensis dan $P$. duvaucelii dengan rumus $\mathrm{K}=$ $\mathrm{W} / \mathrm{aL}^{\mathrm{b}}$ masing- masing adalah 1,007 dan 1,082. Hal tersebut menunjukkan bahwa tubuh dari kedua cumi-cumi yaitu kurang pipih. Berdasarkan penelitian ini, diketahui bahwa pertumbuhan panjang mantel kedua spesies tumbuh lebih cepat dibanding organ tubuh lain dan pertumbuhan panjang mata $P$. chinensis lebih cepat dibanding tinggi mata, sedangkan panjang mata $P$. duvaucelii tumbuh seimbang terhadap tinggi mata.
\end{abstract}

Kata kunci: cumi-cumi, morfometri, panjang berat, Faktor Kondisi

\section{ABSTRACT}

One marine products that have high economic value after the fish and shrimp are squid. The squid is one type of fishery resources is a real role in the marine fisheries sector and consumed by many people. Resource use through squid fishing activity is time accompanied by efforts to capture settings. This effort can repair damaged squid resource, because the stock could be enriched to improve and maintain the sustainability of the squid resource. The study of the morphometry of the squid is necessary in order for the size selectivity of fishing activities. Selectivity of fishing gear is very important to avoid the occurrence of overfishing. This study aims to determine the morphometric characteristics and condition factor of the squid P.chinensis and $P$. duvaucelii landed in several TPI In Northern Coast of Central Java. The method used in this research is descriptive method in which the implementation is done through a survey technique that conduct direct observations in the field by asking the fishermen as the primary data and sampling using a random sampling method is that all members of the population has an equal chance to be included as members of samples. Result this study isiidentified two types of squid i.e., P.chinensis and $P$. duvaucelii. Domination of size for $P$. duvaucelii about $25-40 \mathrm{~mm}$ and $P$. chinensis about $55-70 \mathrm{~mm}$. Length-weight relationship of P.chinensis and P. duvaucelii were $\mathrm{W}=0.0024 \mathrm{~L}^{2,055}$ and $\mathrm{W}=0.00129 \mathrm{~L}^{2,213}$. Allometric characteristics of P.duvaucelii and P.chinensis have a nature allometric growth positive, negative allometric and isometric. By appliying this formula $\mathrm{K}=\mathrm{W} / \mathrm{aL}^{\mathrm{b}}$ condition faktor for P.chinensis and P.duvaucelii were 1,007 and 1,082, showing that bodies of both species were slim. Based on this research, it is known that growth for mantle length of both species faster than other organs. Eye length growth of $P$. chinensis faster than eye height while the eye length $P$. duvaucelii growth was proportion with the eye height growth.

Key words: squid, morphometry, length-weight, Condition Factor

1) Penulis Penanggung Jawab 


\section{Pendahuluan}

Salah satu hasil laut yang memiliki nilai ekonomis tinggi setelah ikan dan udang adalah cumi-cumi. Cumi-cumi merupakan salah satu jenis sumberdaya perikanan yang berperan nyata dalam sektor perikanan laut dan banyak dikonsumsi oleh masyarakat. Cumi-cumi merupakan salah satu jenis dari kelas Cephalopoda, yaitu salah satu kelompok hewan lunak yang tidak memiliki tulang belakang (Mujiono, 2009).

Jawa Tengah memiliki garis pantai 791,76 km terdiri atas panjang pantai utara 502,69 km dan panjang pantai selatan $289,07 \mathrm{~km}$. Propinsi Jawa Tengah memiliki potensi sumberdaya perikanan laut yang sangat besar berupa berbagai jenis ikan pelagis kecil (small pelagic) dan ikan demersal sebesar 796,640ton/tahun, serta potensi udang dan cumi-cumi. Hampir semua jenis sumberdaya ikan di Laut Jawa dieksploitasi secara berlebih yaitu pelagis besar 250,85\%; pelagis kecil 149,27\%; karang konsumsi 509,79\%; udang 463,68\%; lobster 186\% bahkan cumi-cumi sebesar $240,28 \%$. Sumberdaya ikan yang belum mencapai ekploitasi berlebih adalah jenis demersal yaitu mencapai 89,07\%.(Sutanto, 2005).

Pemanfaatan sumberdaya cumi-cumi melalui kegiatan penangkapan sudah saatnya disertai dengan upaya pengaturan penangkapan. Upaya ini dapat memperbaiki kerusakan sumberdaya cumi-cumi karena stok dapat diperkaya untuk memperbaiki dan mempertahankan kelestarian sumberdaya cumi-cumi. Salah satu faktor yang sangat penting untuk mendukung upaya budidaya cumi-cumi adalah adanya ketersediaan (supply) telur dan keberhasilan pemijahan (Tallo, 2006).

Studi mengenai morfometri dari cumi-cumi khususnya Photololigo chinensis dan Photololigo duvaucelii sangat diperlukan guna selektivitas ukuran bagi kegiatan penangkapan. Selektivitas alat tangkap sangat penting dilakukan untuk menghindari terjadinya overfishing. Banyak dari cumi-cumi yang tertangkap masih dalam ukuran kecil yang belum layak untuk ditangkap. Studi morfometri cumi-cumi secara runtun waktu dilakukan untuk menetapkan stok per populasi alamiah. Stok tersebut sekiranya dapat digunakan untuk menentukan produksi maksimum berkelanjutan/MSY (Maximum Sustainable Yield), meskipun perhitungan MSY berada di luar cakupan studi ini.

Tujuan penelitian ini adalah mengetahui karakteristik morfometri dan faktor kondisi dari cumi-cumi P.chinensis dan P. duvaucelii yang didaratkan di beberapa TPI Pantai Utara Jawa Tengah. Penelitian ini dilaksanakan pada bulan November 2012 sampai bulan Februari 2013. Lokasi penelitian yaitu di beberapa TPI Pantai Utara Jawa Tengah antara lain TPI Tambak Lorok Semarang, TPI Ujung Batu Jepara, TPI Morodemak Demak dan TPI Tawang Kendal. Pengukuran dilakukan di Laboratorium Manajemen Sumberdaya Perairan, Jurusan Perikanan, Fakultas Perikanan dan Ilmu Kelautan Universitas Diponegoro Semarang. Hasil penelitian ini diharapkan dapat memberikan informasi tentang potensi jenis cumi-cumi P.chinensis dan P.duvaucelii yang didaratkan di beberapa TPI Pantai Utara Jawa Tengah serta memberikan informasi mengenai aspek biologi cumi-cumi terutama karakteristik morfometri dan tingkat pertumbuhannya.

\section{Materi dan Metode Penelitian}

\section{A. Materi Penelitian}

Materi yang digunakan dalam penelitian ini adalah sampel cumi-cumi yang digunakan dalam pengukuran. Alat yang digunakan dalam penelitian ini adalah penggaris dengan skala $1 \mathrm{~mm}$ dan jangka sorong dengan skala $0,01 \mathrm{~mm}$ untuk mengukur bagian tubuh cumi-cumi, timbangan elektrik 2 digit untuk menimbang bobot tubuh, mikroskop untuk melihat jenis sucker cumi-cumi, kotak styrofoam sebagai tempat sampel, kertas label untuk penanda sampel, freezer untuk tempat menjaga kesegaran cumi-cumi, dan plastik klip untuk menyimpan cumicumi berdasarkan ukuran

\section{B. Metode Penelitian}

Metode yang digunakan dalam penelitian dengan judul analisis morfometri dan faktor kondisi pada cumicumi $P$. chinensis dan $P$. duvaucelii yang didaratkan di beberapa TPI Pantai Utara Jawa Tengah adalah metode deskriptif yang dalam pelaksanaannya dilakukan melalui teknik survei yaitu melakukan kegiatan pengamatan secara langsung dilapangan dengan bertanya terhadap nelayan sebagai data primer

(Suryana, 2010).

\section{Pengambilan sampel}

Sampel diambil dari hasil tangkapan yang didaratkan di beberapa TPI Pantai Utara Jawa Tengah secara acak. Menurut Hadi (2004), dasar pokok dari random sampling adalah bahwa semua anggota populasi mempunyai peluang yang sama untuk dimasukkan sebagai anggota sampel. Sampel tersebut selanjutnya diletakkan dalam freezer sebelum dilakukan identifikasi jenis dan pengukuran di Laboratorium Manajemen Sumberdaya Perairan Jurusan perikanan.

\section{Identifikasi dan Pengukuran Cumi-Cumi}

Identifikasi yang dilakukan yaitu dengan menggunakan buku Identifikasi FAO (2010) dan beberapa variabel yang digunakan dalam pengukuran yaitu Panjang Mantel (PM), Panjang Kepala (PK), Panjang mata (PMT), Tinggi Mata (TMT), Panjang Tentakel (PT), Panjang Gladius (PG), Lebar Gladius (LG), Lebar Mantel (LM), Panjang Sirip (PS), Lebar Sirip (LS), dan Berat Basah (BB). 


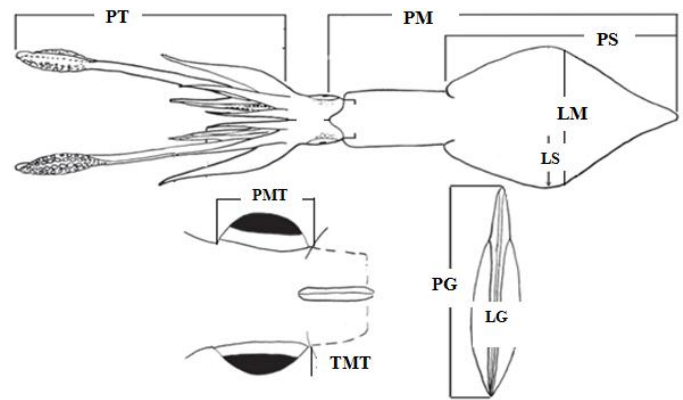

Gambar 1. Pengukuran Morfometri Cumi-Cumi

Analisis Alometrik

Parameter yang akan dibandingkan dapat dikuantifikasi/diukur dengan akurat, maka kaitan antar dua parameter pertumbuhan pada bagian tubuh manapun dapat ditaksir melalui persamaan regresi non-linier, yaitu:

$$
\mathrm{Y}=\mathrm{Ax}{ }^{\mathrm{b}}
$$

Linearisasi persamaan tersebut adalah:

$\log _{10} \mathrm{Y}=\log _{10} \mathrm{~A}+\mathrm{b} \log _{10} \mathrm{x}$

Kriteria alometri dan isometri yang agak berbeda berlaku bila unit pengukuran variabel pertumbuhan yang dibandingkan tidak sama. Misalnya jika Y adalah berat atau volume cangkang $\left(\mathrm{mg}\right.$ atau $\left.\mathrm{mm}^{3}\right)$ sebagai variabel terikat dan $\mathrm{x}$ luas permukaan insang $\left(\mathrm{mm}^{2}\right)$ sebagai variabel bebas, maka koefisien isometri $\beta=3 / 2$. Sehingga bila $\beta=3 / 2$ berarti berat atau volume cangkang bertambah dalam derajat pertumbuhan yang relatif sama dengan pertambahan luas permukaan insang. Alometri positif dan negatif masing-masing berlaku bila $\beta$ $>3 / 2$ dan bila $\beta<3 / 2$. Bila yang dibandingkan misalnya adalah berat cangkang $(\mathrm{mg})$ terhadap panjang cangkang $(\mathrm{mm})$, maka $\beta=3 / 1=3$, dan bila diperbandingkan terhadap beratnya maka $\beta=1 / 3$ (Afiati, 2005)

Secara grafis $\mathrm{X}$ dan $\mathrm{Y}$ adalah variabel bebas dan terikat, sedangkan A dan b masing-masing merupakan intercept dan slope dari grafik regresi yang dihasilkan persamaan (2). Uji statistik sederhana berikut ini digunakan untuk mengetahui penyimpangan dari pola pertumbuhan isometrik atas variabel-variabel yang diperbandingkan (Afiati, 2005):

$$
\operatorname{tobs}(n-1) d f=\frac{(b-\beta)}{\text { Serrordarib }} .
$$

\section{Analisis Hubungan Panjang-Berat}

Pengukuran panjang berat dimulai dengan pengukuran panjang total cumi-cumi menggunakan penggaris dengan ketelitian $0,1 \mathrm{~cm}$ dan jangka sorong dengan ketelitian $0,01 \mathrm{~cm}$. Pengukuran berat tubuh menggunakan timbangan dengan ketelitian 0,01 gram, kemudian dicari hubungan panjang berat dengan rumus:

Analisis data yang dilakukan meliputi perhitungan panjang berat dan faktor kondisi. Hubungan panjang berat dihitung mengunakan persamaan menurut Effendie (2002) adalah sebagai berikut:

$$
\mathrm{W}=\mathrm{aL}^{\mathrm{b}}
$$

Jika angka $b \neq 3$ maka dilanjutkan dengan uji t. Apabila $b=3$ maka pertumbuhan bersifat isometrik, dan apabila $b \neq 3$ maka pertumbuhan bersifat alometrik.

\section{Faktor Kondisi}

Menurut Effendie (2002), perhitungan faktor kondisi ini berkaitan dengan perhitungan analisis hubungan panjang berat Photololigo chinensis dan Photololigo duvaucelii yang telah dilakukan sebelumnya. Apabila nilai $b=3$ (pola pertumbuhan isometrik) untuk perhitungan faktor kondisi digunakan rumus :

$$
K(T I)=\frac{10^{3} \times W}{L^{3}}
$$

Apabila dari hasil perhitungan yang didapat adalah angka $b \neq 3$ (pola pertumbuhan alometrik) maka faktor kondisi dihitung dengan rumus:

$$
K=\frac{W}{a L}
$$

Dimana :

- $\mathrm{K}(\mathrm{TI}) \quad=$ Faktor kondisi dalam panjang total

- $\mathrm{W} \quad=$ Berat rata-rata cumi-cumi dalam gram yang terdapat dalam suatu kelas 
- $\mathrm{L} \quad=$ Panjang mantel rata-rata cumi-cumi dalam $\mathrm{cm}$ yang terdapat dalam kelas tersebut.

- $\quad$ a dan b konstanta

Harga K sebenarnya tidak berarti apa-apa, akan tetapi terlihat kegunaannya apabila telah dibandingkan dengan individu lainnya antara satu grup dengan grup lainnya. Harga $\mathrm{K}$ itu berkisar antara $2-4$ apabila bentuk agak pipih, sedangkan bila badannya kurang pipih maka harga K berkisar antara $1-3$ (Effendie, 2002).

\section{Uji Perbandingan Variabel Morfometri pada Kedua Spesies Cumi-Cumi}

Untuk mengetahui perbedaan tipe morfometri cumi-cumi, maka dilakukan uji dua contoh KolmogorovSmirnov dan Uji Mann-Whitney. Data yang telah didapat dari penetapan sifat morfometri kemudian dianalisis dengan bantuan program SPSS versi 16. Menurut Safar et al (2007), hal itu dilakukan untuk menguji dua sampel independen dan menguji hipotesis nol bahwa mereka berasal dari populasi yang identik. Uji Mann-Whitney digunakan untuk menguji hipotesis nol tentang kesamaan parameter-parameter lokasi populasi. Dalam beberapa kasus uji ini disebut juga uji Mann-Whitney Wilcoxon, karena Wilcoxon menggunakan kasus dengan ukuran sampel yang sama sedangkan Mann-Whitney dapat juga menggunakan ukuran sampel yang berbeda (Safar et al, 2007).

Uji Mann-Whitney merupakan uji statistika nonparametrik, alternatif dari uji t dua sampel independen. Uji Mann-Whitney digunakan untuk membandingkan dua sampel independen dengan skala ordinal atau skala interval tapi tidak terdistribusi normal (Uyanto, 2009).

Asumsi yang berlaku dalam uji Mann-Whitney adalah:

a.Mengasumsikan bahwa sampel yang berasal dari populasi adalah acak,

b.Sampel bersifat independen (berdiri sendiri),

c.Skala pengukuran yang digunakan adalah skala ordinal.

\section{Hasil dan Pembahasan}

Jenis Cumi-cumi yang Diidentifikasi

Berdasarkan penelitian ini diidentifikasi dua jenis spesies cumi-cumi yaitu $P$. chinensis dan P.duvaucelii. Karakteristik cumi-cumi P.chinensis dan P.duvaucelii adalah sebagai berikut:

a. Photololigo chinensis

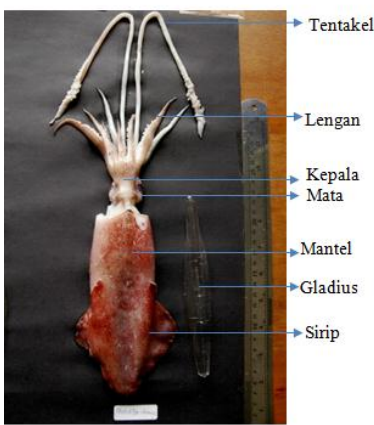

b. Photololigo duvaucelii

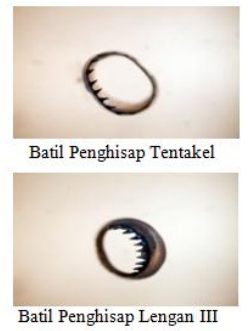

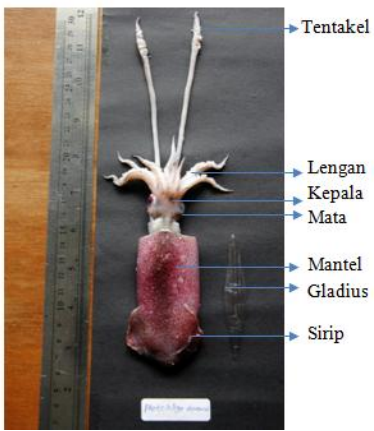
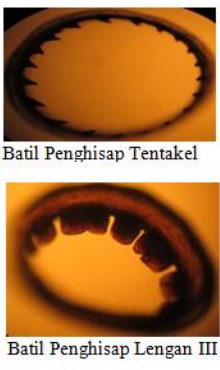

Gambar 2. Cumi-Cumi P. chinensis dan P. duvaucelii serta Batil Penghisap

Berdasarkan identifikasi jenis cumi-cumi yang didapat yaitu $P$. chinensis berjumlah 132 individu dan $P$. duvaucelii berjumlah 130 individu. Kedua spesies cumi-cumi tersebut mempunyai karakteristik yaitu mantel yang kokoh dengan sirip berbentuk belah ketupat, lebar, pendek, dan panjangnya 50\% dari panjang mantel untuk $P$. duvaucelii dan $60 \%$ untuk P.chinensis. Berdasarkan pengamatan batil penghisap melalui miksroskop yang terletak di tentakel (club sucker) yaitu P.chinensis mempunyai 20-30 gigi tajam dan P.duvaucelii mempunyai 14-22 gigi tajam. Lengan IV pada cumi-cumi merupakan alat untuk membedakan jenis kelamin pada cumi-cumi. Individu jantan adalah hektokotilus yang artinya pada lengan IV pada cumi-cumi berevolusi dari bentuk sebelumnya.

\section{Struktur Populasi}

Struktur populasi berdasarkan frekuensi dan panjang mantel, dengan kisaran panjang mantel P. duvaucelii 25 - $133 \mathrm{~mm}$ dan P.chinensis 28,3 - $203 \mathrm{~mm}$ yang diperoleh tersaji pada Gambar 3. 

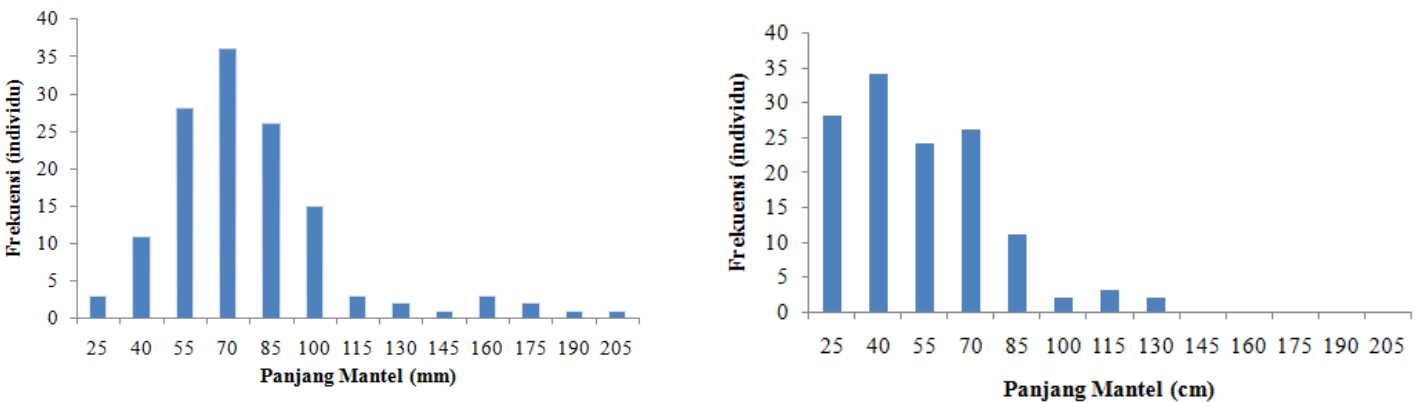

Gambar 3. Struktur Populasi P. chinensis dan P. duvaucelii

Berdasarkan struktur populasi kedua spesies cumi-cumi tersebut, ukuran panjang mantel rata-rata P.chinensis adalah 84,28 $\pm 29,56 \mathrm{~mm}$ dengan individu terbanyak pada $P$. chinensis yaitu antara ukuran $55-70$ mm. Panjang mantel rata-rata $P$.duvaucelii adalah $60,55 \pm 23,75 \mathrm{~mm}$ dengan ukuran yang mendominasi untuk $P$. duvaucelii yaitu berkisar antara $25-40 \mathrm{~mm}$. Data ukuran tersebut menunjukkan bahwa $P$. duvaucelii lebih banyak didaratkan di TPI Pantai Utara Jawa Tengah saat berukuran kecil karena ukuran yang lebih banyak didapat berkisar antara $25-70 \mathrm{~mm}$ jika dibandingkan dengan $P$. chinensis yang dominan pada ukuran $55-100$ $\mathrm{mm}$.

\section{Analisis Hubungan Panjang Berat}

Total sampel P.duvaucelii yang didapat sebanyak 130 individu memiliki kisaran panjang mantel $25 \mathrm{~mm}$ sampai $133 \mathrm{~mm}$ dan kisaran berat 1,4 gr sampai 60,13 gr, sedangkan sampel P.chinensis yang didapat sebanyak 132 individu memiliki kisaran panjang mantel 28,3 mm sampai $205 \mathrm{~mm}$ dan berat berkisar antara 0,75 gr sampai 85,3 gr yang selanjutnya dianalisis sesuai dengan tujuan penelitian. Hasil analisis hubungan panjang berat terhadap P.duvaucelii dan P.chinenis disajikan pada Tabel 1.

Tabel 1. Hubungan Panjang Berat Cumi-Cumi P.chinensis dan P. duvauceli yang Didaratkan di Beberapa TPI Pantai Utara Jawa Tengah

\begin{tabular}{cccccc}
\hline Spesies & $\begin{array}{c}\text { Jumlah Sampel } \\
(\mathrm{n})\end{array}$ & Intercept $(\mathrm{a})$ & $\begin{array}{c}\text { Slope } \\
(\mathrm{b})\end{array}$ & $\mathrm{r}$ & $\mathrm{W}^{2} \mathrm{a} \mathrm{L}^{\mathrm{b}}$ \\
\hline P.duvaucelii & 130 & 0,0024 & 2,055 & 0,885 & $0,0024 \mathrm{~L}^{2,055}$ \\
P. chinensis & 132 & 0,00129 & 2,213 & 0,927 & $0,00129 \mathrm{~L}^{2,213}$ \\
\hline
\end{tabular}

Berdasarkan analisis di atas maka grafik korelasi panjang berat $P$. chinenis dan P.duvaucelii selama penelitian dapat dilihat pada Gambar 4.
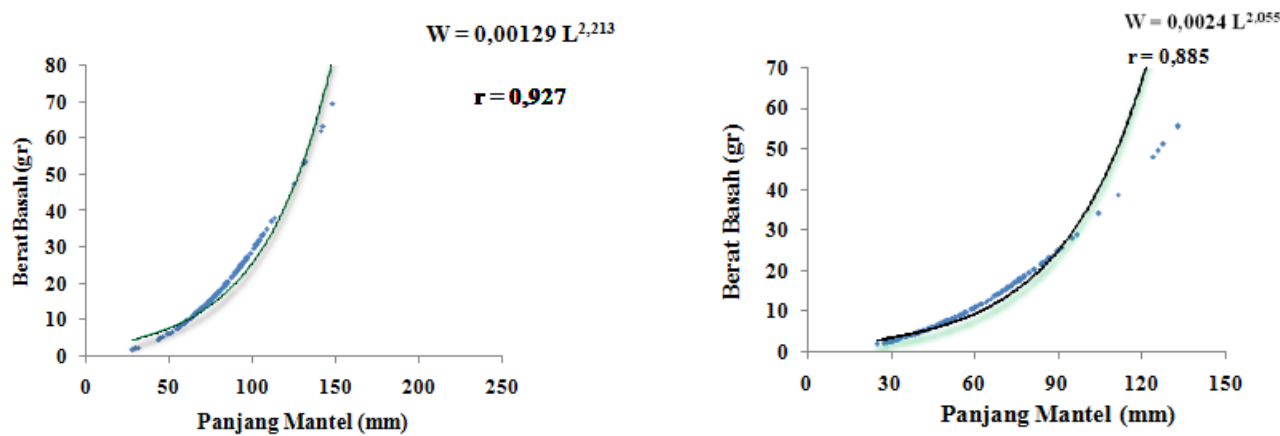

Gambar 4. Hubungan Panjang Berat P. chinenis dan P. duvaucelii Berdasarkan Panjang Mantel

Berdasarkan analisis dan bentuk grafik di atas, bahwa angka slope (b) yang didapat adalah kurang dari angka 3 yang berarti pertambahan panjang mantel lebih cepat daripada pertambahan berat. Persamaan yang dihasilkan dari analisis panjang berat dapat menduga suatu nilai bobot cumi-cumi berdasarkan panjang mantel. Berdasarkan grafik tersebut terlihat bahwa pada awal pertumbuhannya, pertambahan panjang panjang lebih cepat dibanding pertambahan berat, namun ketika berukuran besar pertambahan bobot pada $P$. duvaucelii lebih cepat dibanding $P$. chinensis. 
Faktor Kondisi

Serupa dengan perhitungan hubungan panjang berat, nilai faktor kondisi P.duvaucelii dan P. chinensis selama penelitian tertera pada Tabel 2.

Tabel 2. Angka Faktor Kondisi P.duvaucelii dan P. chinensis yang Didaratkan di Beberapa TPI Pantai Utara Jawa Tengah

\begin{tabular}{cccccc}
\hline Spesies & $\begin{array}{c}\text { Jumlah } \\
\text { sampel }(\mathrm{n})\end{array}$ & $\begin{array}{c}\text { Panjang } \\
\text { Rata-rata }(\mathrm{L}) \\
(\mathrm{mm})\end{array}$ & $\begin{array}{c}\text { berat rata-rata } \\
(\mathrm{W})(\text { gram })\end{array}$ & $\begin{array}{c}\text { rata-rata } \\
\mathrm{W}=\mathrm{a} \mathrm{L}^{\mathrm{b}}\end{array}$ & $\mathrm{Kn}=\mathrm{w} / \mathrm{W}$ \\
\hline P.duvaucelii & 130 & $60,55 \pm 23,75$ & 13,916 & 12,861 & 1,082 \\
P.chinensis & 132 & $84,28 \pm 29,56$ & 23,326 & 23,151 & 1,007 \\
\hline
\end{tabular}

Hasil perhitungan faktor kondisi menunjukkan bahwa angka faktor kondisi berkisar $1-3$, berarti cumicumi P.duvaucelii dan P. chinensis memiliki badan yang kurang pipih. Sebagaimana dilihat kedua spesies memiliki gladius sebagai rangka tipis antero-posterior yang relatif sangat ringan terhadap bobot total tubuh; sehingga disimpulkan bahwa relatif semua bagian tubuh kedua spesies adalah edible portion (bagian yang dapat dikonsumsi).

\section{Analisis Alometrik}

\section{a. Alometri Cumi-Cumi P. duvaucelii}

Berdasarkan lokasi penelitian diperoleh ukuran panjang mantel rata-rata P.duvaucelii adalah $60,55 \pm$ 23,75 mm dengan kisaran panjang $25-133 \mathrm{~mm}$. Dimensi pengukuran morfometrik yang dilakukan terhadap $P$. duvaucelii menghasilkan tipe pertumbuhan isometrik, alometri negatif, dan alometri positif sebagaimana tersaji pada Tabel 3.

Tabel 3. Pertumbuhan Alometrik Beberapa Variabel Morfometrik P.duvaucelii yang Didaratkan di TPI Pantai Utara Jawa Tengah, $\mathrm{n}=130$

\begin{tabular}{|c|c|c|c|c|c|c|c|c|c|}
\hline \multicolumn{2}{|c|}{ Variabel } & \multirow{2}{*}{ A } & \multirow{2}{*}{$\mathrm{b}$} & \multirow{2}{*}{ beta } & \multirow{2}{*}{$\mathrm{S}_{\mathrm{eb}}$} & \multirow{2}{*}{$\mathrm{r}$} & \multirow{2}{*}{$\mathrm{R}$} & \multirow{2}{*}{$\mathrm{t}_{\text {hitung }}$} & \multirow{2}{*}{ Alometri } \\
\hline Bebas & Terikat & & & & & & & & \\
\hline \multirow[t]{10}{*}{ PM } & PK & 0,020 & 0,665 & 1 & 0,025 & 0,923 & 0,851 & $-13,400 *$ & - \\
\hline & PMT & 0,075 & 0,575 & 1 & 0,020 & 0,929 & 0,863 & $-21,250 *$ & - \\
\hline & TMT & $-0,192$ & 0,631 & 1 & 0,027 & 0,903 & 0,815 & $-13,667 *$ & - \\
\hline & PT & 0,900 & 0,639 & 1 & 0,054 & 0,725 & 0,526 & $-6,685^{*}$ & - \\
\hline & PS & $-0,439$ & 1,067 & 1 & 0,027 & 0,960 & 0,922 & $2,481 *$ & + \\
\hline & LS & $-0,101$ & 0,663 & 1 & 0,044 & 0,800 & 0,639 & $-7,659 *$ & - \\
\hline & $\mathrm{PG}$ & 0,070 & 0,967 & 1 & 0,008 & 0,996 & 0,992 & $-1,125^{\mathrm{ns}}$ & Isometrik \\
\hline & $\mathrm{LG}$ & $-0,137$ & 0,648 & 1 & 0,035 & 0,851 & 0,724 & $-10,057 *$ & - \\
\hline & LM & 0,119 & 0,696 & 1 & 0,025 & 0,928 & 0,861 & $-12,160 *$ & - \\
\hline & $\mathrm{BB}$ & $-2,619$ & 2,056 & 3 & 0,096 & 0,885 & 0,783 & $-9,833^{*}$ & - \\
\hline \multirow[t]{9}{*}{ PK } & TMT & $-0,080$ & 0,839 & 1 & 0,043 & 0,865 & 0,748 & $-3,744 *$ & - \\
\hline & PMT & 0,161 & 0,777 & 1 & 0,032 & 0,905 & 0,818 & $-6,969 *$ & - \\
\hline & PT & 1,074 & 0,797 & 1 & 0,082 & 0,652 & 0,425 & $-2,476^{*}$ & - \\
\hline & PS & $-0,236$ & 1,408 & 1 & 0,056 & 0,912 & 0,832 & $7,286^{*}$ & + \\
\hline & LS & 0,026 & 0,874 & 1 & 0,066 & 0,759 & 0,576 & $-1,909^{\mathrm{ns}}$ & Isometrik \\
\hline & $\mathrm{PG}$ & 0,288 & 1,247 & 1 & 0,046 & 0,924 & 0,854 & $5,370 *$ & + \\
\hline & LG & 0,011 & 0,853 & 1 & 0,055 & 0,806 & 0,650 & $-2,673 *$ & - \\
\hline & LM & 0,262 & 0,908 & 1 & 0,045 & 0,872 & 0,761 & $-2,044 *$ & - \\
\hline & $\mathrm{BB}$ & $-2,265$ & 2,742 & 3 & 0,015 & 0,850 & 0,723 & $-17,200 *$ & - \\
\hline \multirow[t]{8}{*}{ PMT } & TMT & $-0,190$ & 1,020 & 1 & 0,043 & 0,903 & 0,815 & $0,465^{\mathrm{ns}}$ & Isometrik \\
\hline & PT & 1,331 & 0,753 & 1 & 0,089 & 0,597 & 0,356 & $-2,775^{*}$ & - \\
\hline & PS & $-0,345$ & 1,642 & 1 & 0,065 & 0,914 & 0,835 & $9,877 *$ & + \\
\hline & LS & $-0,033$ & 1,011 & 1 & 0,078 & 0,754 & 0,569 & $0,141^{\mathrm{ns}}$ & Isometrik \\
\hline & $\mathrm{PG}$ & 0,190 & 1,455 & 1 & 0,052 & 0,927 & 0,859 & $8,750 *$ & + \\
\hline & LG & $-0,108$ & 1,023 & 1 & 0,061 & 0,831 & 0,690 & $0,377^{\mathrm{ns}}$ & Isometrik \\
\hline & LM & 0,177 & 1,073 & 1 & 0,050 & 0,886 & 0,784 & $1,460 \mathrm{~ns}$ & Isometrik \\
\hline & $\mathrm{BB}$ & $-2,349$ & 3,080 & 3 & 0,019 & 0,820 & 0,673 & $4,211^{*}$ & + \\
\hline \multirow[t]{7}{*}{ TMT } & PT & 1,331 & 0,753 & 1 & 0,089 & 0,597 & 0,356 & $-2,775^{*}$ & - \\
\hline & PS & 0,159 & 1,392 & 1 & 0,068 & 0,875 & 0,766 & $5,765^{*}$ & + \\
\hline & LS & 0,234 & 0,904 & 1 & 0,068 & 0,762 & 0,581 & $-1,412^{\mathrm{ns}}$ & Isometrik \\
\hline & PG & 0,615 & 1,258 & 1 & 0,052 & 0,905 & 0,818 & $4,962 *$ & + \\
\hline & $\mathrm{LG}$ & 0,211 & 0,862 & 1 & 0,059 & 0,791 & 0,625 & $-2,339 *$ & - \\
\hline & LM & 0,528 & 0,886 & 1 & 0,054 & 0,826 & 0,682 & $-2,111 *$ & - \\
\hline & $\mathrm{BB}$ & $-1,433$ & 2,655 & 3 & 0,177 & 0,798 & 0,638 & $-1,949^{\mathrm{ns}}$ & Isometrik \\
\hline
\end{tabular}


Lanjutan Tabel 3. Pertumbuhan Alometrik Beberapa Variabel Morfometrik P.duvaucelii yang Didaratkan di TPI Pantai Utara Jawa Tengah, $\mathrm{n}=130$

\begin{tabular}{|c|c|c|c|c|c|c|c|c|c|}
\hline \multicolumn{2}{|c|}{ Variabel } & \multirow{2}{*}{ A } & \multirow{2}{*}{$\mathrm{b}$} & \multirow{2}{*}{ beta } & \multirow{2}{*}{$\mathrm{S}_{\mathrm{eb}}$} & \multirow{2}{*}{$\mathrm{r}$} & \multirow{2}{*}{$\mathrm{R}$} & \multirow{2}{*}{$\mathrm{t}_{\text {hitung }}$} & \multirow{2}{*}{ Alometri } \\
\hline Bebas & Terikat & & & & & & & & \\
\hline \multirow[t]{6}{*}{ PS } & PT & 1,211 & 0,564 & 1 & 0,049 & 0,712 & 0,507 & $-8,898 *$ & - \\
\hline & $\mathrm{LS}$ & 0,188 & 0,610 & 1 & 0,038 & 0,817 & 0,668 & $-10,263 *$ & - \\
\hline & PG & 0,561 & 0,840 & 1 & 0,021 & 0,961 & 0,924 & $-7,619 *$ & - \\
\hline & LG & 0,131 & 0,606 & 1 & 0,028 & 0,884 & 0,782 & $-14,071 *$ & - \\
\hline & LM & 0,467 & 0,608 & 1 & 0,026 & 0,902 & 0,813 & $-15,077 *$ & - \\
\hline & BB & $-1,629$ & 1,825 & 3 & 0,090 & 0,873 & 0,762 & $-13,056^{*}$ & - \\
\hline \multirow[t]{5}{*}{ LS } & PT & 1,367 & 0,614 & 1 & 0,077 & 0,578 & 0,333 & $-5,013 *$ & - \\
\hline & PG & 0,768 & 0,939 & 1 & 0,062 & 0,801 & 0,642 & $-0,984^{\mathrm{ns}}$ & Isometrik \\
\hline & LG & 0,334 & 0,623 & 1 & 0,060 & 0,679 & 0,461 & $-6,283 *$ & - \\
\hline & LM & 0,616 & 0,680 & 1 & 0,053 & 0,752 & 0,566 & $-6,038 *$ & - \\
\hline & BB & $-1,190$ & 2,047 & 3 & 0,169 & 0,731 & 0,534 & $-5,639 *$ & - \\
\hline \multirow[t]{4}{*}{ PG } & PT & 0,852 & 0,661 & 1 & 0,055 & 0,729 & 0,531 & $-6,164 *$ & - \\
\hline & LG & $-0,190$ & 0,673 & 1 & 0,035 & 0,859 & 0,738 & $-9,343 *$ & - \\
\hline & LM & 0,810 & 0,712 & 1 & 0,026 & 0,923 & 0,852 & $-11,077 *$ & - \\
\hline & $\mathrm{BB}$ & $-2,734$ & 2,106 & 3 & 0,100 & 0,881 & 0,776 & $-8,940^{*}$ & - \\
\hline
\end{tabular}

Keterangan:

$+\quad=$ Allometrik Positif

- $\quad$ = Allometrik Negatif

* $\quad=$ Berbeda nyata pada $\mathrm{p}<0.05\left(\mathrm{n}=\infty, \mathrm{t}_{0.05}=1.967\right)$

ns $\quad=$ Tidak berbeda nyata pada $\mathrm{p}>0.05$

Notasi variabel : lihat Gambar 1

b. Alometri Cumi-Cumi P. chinensis

Berdasarkan lokasi penelitian diperoleh ukuran panjang mantel rata-rata P.chinensi sadalah 84,28 \pm $29,56 \mathrm{~mm}$ dengan kisaran 28,30 - $203 \mathrm{~mm}$. Dimensi pengukuran morfometrik yang dilakukan terhadap P.chinensis menghasilkan tipe pertumbuhan isometrik, alometri negatif, dan alometri positif sebagaimana tersaji pada Tabel 5.

Tabel 4. Pertumbuhan Alometrik Beberapa Variabel Morfometrik P.chinensis yang Didaratkan di TPI Pantai Utara Jawa Tengah, $\mathrm{n}=132$

\begin{tabular}{|c|c|c|c|c|c|c|c|c|c|}
\hline \multicolumn{2}{|c|}{ Variabel } & \multirow{2}{*}{ A } & \multirow{2}{*}{$\mathrm{b}$} & \multirow{2}{*}{ beta } & \multirow{2}{*}{$\mathrm{S}_{\mathrm{eb}}$} & \multirow[b]{2}{*}{$\mathrm{r}$} & \multirow{2}{*}{$\mathrm{R}$} & \multirow[b]{2}{*}{$\mathrm{t}_{\text {hitung }}$} & \multirow{2}{*}{ Alometri } \\
\hline Bebas & Terikat & & & & & & & & \\
\hline \multirow[t]{8}{*}{ PM } & PK & 0,068 & 0,628 & 1 & 0,0360 & 0,835 & 0,698 & $-10,333 *$ & - \\
\hline & PMT & 0,009 & 0,581 & 1 & 0,0420 & 0,771 & 0,594 & $-9,9762 *$ & - \\
\hline & TMT & $-0,296$ & 0,658 & 1 & 0,0320 & 0,877 & 0,768 & $-10,6875^{*}$ & - \\
\hline & PT & 0,435 & 0,855 & 1 & 0,0560 & 0,802 & 0,643 & $-2,5893^{*}$ & - \\
\hline & PS & $-0,802$ & 1,258 & 1 & 0,0290 & 0,968 & 0,937 & $8,8966^{*}$ & + \\
\hline & LG & $-0,311$ & 0,738 & 1 & 0,0460 & 0,815 & 0,665 & $-5,6957 *$ & - \\
\hline & LM & 0,032 & 0,717 & 1 & 0,0390 & 0,848 & 0,719 & $-7,2564 *$ & - \\
\hline & BB & $-2,952$ & 2,213 & 3 & 0,078 & 0,928 & 0,861 & $-10,087$ & - \\
\hline \multirow[t]{6}{*}{$\mathrm{PK}$} & TMT & $-0,057$ & 0,801 & 1 & 0,0520 & 0,803 & 0,644 & $-3,8269 *$ & - \\
\hline & PMT & 0,116 & 0,791 & 1 & 0,0540 & 0,788 & 0,622 & $-3,8704 *$ & - \\
\hline & PG & 0,542 & 1,084 & 1 & 0,0660 & 0,822 & 0,676 & $1,2727^{\mathrm{ns}}$ & Isometrik \\
\hline & LG & 0,090 & 0,795 & 1 & 0,0790 & 0,66 & 0,436 & $-2,5949 *$ & - \\
\hline & LM & 0,337 & 0,839 & 1 & 0,0660 & 0,746 & 0,557 & $-2,4394 *$ & - \\
\hline & BB & $-1,933$ & 2,525 & 3 & 0,1680 & 0,796 & 0,634 & $-2,825^{*}$ & - \\
\hline \multirow[t]{6}{*}{ PMT } & TMT & 0,016 & 0,842 & 1 & 0,0470 & 0,846 & 0,716 & $-3,3617 *$ & - \\
\hline & PT & 0,877 & 1,063 & 1 & 0,0820 & 0,752 & 0,565 & $0,7683^{\mathrm{ns}}$ & Isometrik \\
\hline & PS & 0,077 & 1,358 & 1 & 0,0930 & 0,788 & 0,62 & $3,8495^{*}$ & + \\
\hline & $\mathrm{LS}$ & $-0,259$ & 1,245 & 1 & 0,1200 & 0,673 & 0,453 & $2,0417 *$ & + \\
\hline & PG & 0,797 & 0,999 & 1 & 0,0750 & 0,759 & 0,577 & $-0,0133^{\mathrm{ns}}$ & Isometrik \\
\hline & LG & 0,242 & 0,764 & 1 & 0,0810 & 0,636 & 0,405 & $-2,9136 *$ & - \\
\hline
\end{tabular}


http://ejournal-s1.undip.ac.id/index.php/maquares

Lanjutan Tabel 4. Pertumbuhan Alometrik Beberapa Variabel Morfometrik P.chinensis yang Didaratkan di TPI Pantai Utara Jawa Tengah, $\mathrm{n}=132$

\begin{tabular}{|c|c|c|c|c|c|c|c|c|c|}
\hline \multicolumn{2}{|c|}{ Variabel } & \multirow[t]{2}{*}{$\mathrm{a}$} & \multirow[t]{2}{*}{$\mathrm{b}$} & \multirow[t]{2}{*}{ beta } & \multirow[t]{2}{*}{$\mathrm{S}_{\mathrm{eb}}$} & \multirow[t]{2}{*}{$\mathrm{r}$} & \multirow[t]{2}{*}{$\mathrm{R}$} & \multirow[t]{2}{*}{$t_{\text {hitung }}$} & \multirow[t]{2}{*}{ Alometri } \\
\hline Bebas & Terikat & & & & & & & & \\
\hline \multirow{9}{*}{ PS } & PG & 0,827 & 1,135 & 1 & 0,0590 & 0,859 & 0,738 & $2,2881 *$ & + \\
\hline & LG & 0,260 & 0,873 & 1 & 0,0730 & 0,724 & 0,524 & $-1,7397^{\mathrm{ns}}$ & Isometrik \\
\hline & LM & 0,540 & 0,897 & 1 & 0,0600 & 0,796 & 0,633 & $-1,7167^{\mathrm{ns}}$ & Isometrik \\
\hline & $\mathrm{BB}$ & $-1,377$ & 2,758 & 3 & 0,1390 & 0,868 & 0,753 & $-1,7410^{\mathrm{ns}}$ & Isometrik \\
\hline & PT & 0,955 & 0,696 & 1 & 0,0380 & 0,848 & 0,72 & $-8,0000 *$ & - \\
\hline & PG & 0,743 & 0,734 & 1 & 0,0180 & 0,962 & 0,926 & $-14,7778 *$ & - \\
\hline & LG & 0,193 & 0,566 & 1 & 0,0360 & 0,813 & 0,661 & $-12,0556 *$ & - \\
\hline & LM & 0,507 & 0,559 & 1 & 0,0290 & 0,86 & 0,739 & $-15,2069 *$ & - \\
\hline & $\mathrm{BB}$ & $-1,477$ & 1,718 & 3 & 0,0570 & 0,936 & 0,877 & $-22,492 *$ & - \\
\hline \multirow[t]{2}{*}{ LS } & PT & 1,418 & 0,570 & 1 & 0,0450 & 0,745 & 0,556 & $-9,5556 *$ & - \\
\hline & PG & 1,268 & 0,570 & 1 & 0,0370 & 0,801 & 0,642 & $-11,6216 *$ & - \\
\hline \multirow[t]{4}{*}{ PG } & PT & 0,852 & 0,661 & 1 & 0,055 & 0,729 & 0,531 & $-6,164 *$ & - \\
\hline & LG & $-0,190$ & 0,673 & 1 & 0,035 & 0,859 & 0,738 & $-9,343 *$ & - \\
\hline & LM & 0,810 & 0,712 & 1 & 0,026 & 0,923 & 0,852 & $-11,077 *$ & - \\
\hline & $\mathrm{BB}$ & $-2,987$ & 2,221 & 3 & 0,0810 & 0,924 & 0,853 & $-9,617 *$ & - \\
\hline
\end{tabular}

Keterangan:

$+\quad=$ Allometrik Positif

- $\quad=$ Allometrik Negatif

* $\quad=$ Berbeda nyata pada $\mathrm{p}<0.05\left(\mathrm{n}=\infty, \mathrm{t}_{0.05}=1.967\right)$

ns $\quad=$ Tidak berbeda nyata pada $\mathrm{p}<0.05$

Notasi variabel : lihat Gambar 1

\section{Pembahasan}

\section{Jenis Cumi-Cumi yang Diidentifikasi}

Penelitian ini mengidentifikasi 2 jenis cumi-cumi yaitu P.chinensis dan P.duvaucelii. Jenis cumi-cumi P.chinensis yang didapat berjumlah 132 spesimen dan banyak didaratkan di sekitar perairan Kendal dan Semarang, sementara cumi-cumi P.duvaucelii berjumlah 130 spesimen, cumi-cumi P.duvaucelii lebih banyak didaratkan di daerah Jepara dan Demak. Secara umum jenis cumi-cumi P.chinensis dan P.duvauceli terlihat mempunyai ciri-ciri morfologi yang sama. Berdasarkan bentuk mantel, kedua spesies ini mempunyai ciri yang hampir sama yaitu berbentuk belah ketupat. Perbedaaan kedua jenis cumi-cumi ini terletak pada cincin penghisap yang terletak di tentakel (club sucker) yaitu P.chinensis mempunyai 20-30 gigi tajam dan P.duvaucelii mempunyai 14-22 gigi tajam (Jereb and Roper, 2010).

Cumi-cumi P.chinensis merupakan hasil tangkapan sampingan dengan menggunakan pukat udang terutama di Indonesia, dan Malaysia. Cumi-cumi P.duvaucelii lebih banyak ditangkap menggunakan trawl di sekitar perairan Laut Cina Selatan dan Laut Filiphina (Carpenter and Niem, 1998). Di Indonesia sendiri terutama di pantai Utara Jawa, khusunya Jawa Tengah penangkapan cumi-cumi banyak dilakukan dengan pukat, dogol maupun arad. Alat tangkap tersebut sudah dilarang karena justru akan mengurangi stok cumi-cumi di perairan. Menurut Imron (2008), Nilai CPUE (Catch Per Unit Effort) cumi-cumi cenderung semakin menurun dari tahun ke tahun. Penurunan ini diduga karena potensi cumi-cumi sebagai sumberdaya perikanan semakin menurun seiring dengan semakin tingginya upaya penangkapan dari tahun ke tahun.

\section{Hubungan Panjang Berat dan Faktor Kondisi}

Hubungan panjang berat menunjukkan pendugaan terhadap panjang dan berat cumi-cumi atau sebaliknya. Hasil analisis panjang berat cumi-cumi P.duvaucelii dari 130 spesimen mempunyai persamaan $\mathrm{W}=$ $0,0024 \mathrm{~L}^{2,055}$ dengan angka b sebesar 2,055. Penelitian sebelumnya terhadap P.duvaucelii yang dilakukan Karnik and Chakraborty (2001), di perairan Mumbai, India bahwa angka panjang berat yang diperoleh adalah 0,001816L ${ }^{2,1617}$. Cumi-cumi P.chinensis dari 132 spesimen memperoleh persamaan 0,00129 $\mathrm{L}^{2,213}$ dengan angka slope (b) sebesar 2,213. Nilai b dari kedua spesies menunjukkan pola pertumbuhan alometrik negatif yaitu pertumbuhan panjang lebih cepat dari pertumbuhan berat (Effendie, 2002). Hubungan panjang berat P.chinensis baik jantan maupun betina mempunyai angka kisaran slope (b) antara 2,08- 2,68 meskipun sangat berbeda bentuk tubuh maupun ukuran (Jackson, 1991).

Faktor yang menyebabkan perbedaan panjang berat dapat disebabkan oleh faktor ekologi maupun biologi dari cumi-cumi. Faktor-faktor tersebut sesuai dengan pernyataan Sulistiono et al, (2001), dimana hubungan panjang berat menunjukkan pertumbuhan yang bersifat relatif artinya dapat berubah menurut waktu. Apabila terjadi perubahan terhadap lingkungan dan ketersediaan makanan diperkirakan nilai ini juga akan berubah. Berdasarkan hasil analisis panjang berat, nilai koefisien korelasi (r) yang merupakan ukuran kesesuaian 
yaitu sebesar 0,927 pada P.chinensis dan pada P.duvaucelii sebesar 0,885. Hal tersebut menunujukkan bahwa korelasi antara panjang dan berat siginfikan (Hadi, 2004). Besar keeratan hubungannya ditentukan oleh masingmasing koefisien determinasinya (R), nilai koefisien determinasi pada P.duvaucelii dan P.chinensis yaitu 0,859 dan 0,783 artinya pertambahan berat P.duvaucelii dan P.chinensis sekitar $85,9 \%$ dan $78,3 \%$ dapat dijelaskan oleh besarnya pertambahan panjang melalui hubungan regresinya.

Berdasarkan penelitian ini, nilai faktor kondisi cumi-cumi P.chinensis dan P.duvauceli yaitu 1,007 dan 1,082, dari angka tersebut dapat dinyatakan bahwa kedua spesies cumi-cumi yang didaratkan di TPI Pantai Utara Jawa Tengah memiliki bentuk kurang pipih. Menurut Effendie (2002), bahwa kriteria Faktor Kondisi yaitu 2 - 4, berarti badan ikan agak pipih. Jika nilai faktor kondisi berkisar $1-3$, berarti badan ikan kurang pipih. Faktor kondisi sangat dipengaruhi oleh pola pertumbuhannya, ikan-ikan yang memiliki pola pertumbuhan alometrik, jika semakin besar panjang dan bobotnya maka semakin kecil faktor kondisinya. Pola pertumbuhan isometrik yaitu jika semakin besar bobotnya maka semakin besar pula faktor kondisinya (Nurdawati,2010).

\section{Analisis Alometri dan Morfometri Cumi-Cumi}

Berdasarkan hasil analisis alometri cumi-cumi P.chinensis dan P.duvaucelii didapatkan, bahwa ada bagian tubuh yang tumbuh kembangnya proporsional atau seimbang terhadap bagian tubuh yang lain atau isometrik; namun adapula beberapa organ yang tumbuh allometrik, baik positif maupun negatif. Panjang mantel merupakan bagian penting dalam analisis morfometri cumi-cumi karena menentukan bentuk tiga dimensi bagian tubuh yang lain termasuk berat tubuh. Berdasarkan analisis alometri panjang mantel $P$. duvaucelii tampak bahwa panjang mantel tumbuh lebih cepat daripada bagian tubuh yang lain, kecuali terhadap panjang gladius dan panjang sirip. Panjang mantel P.chinensis tumbuh lebih cepat terhadap bagian tubuh yang lain kecuali pada panjang gladius, panjang sirip, dan lebar sirip. Menurut Liao et al, (2010), panjang mantel sangat mempengaruhi pertumbuhan terutama penambahan bobotnya, panjang mantel juga digunakan sebagai dasar pembanding untuk mempermudah pengelompokan pertumbuhan pada cumi-cumi.

Variabel pertumbuhan tubuh yang isometrik antara P.duvaucelii dan P. chinensis yaitu panjang mantel terhadap panjang gladius. Secara keseluruhan panjang gladius mempunyai ukuran yang hampir sama dengan panjang mantel, ini sangat cocok karena pengukuran yang mudah tetapi tidak dapat digunakan untuk panjang total (Boyle and Rodhouse, 2005)

Mata pada cumi-cumi berkembang luar biasa, karena alat penglihatan ini berperan penting dalam kehidupannya (Jereb and Roper, 2010). Pertumbuhan mata P.chinensis dan P.duvaucelii yang diukur melalui panjang mata dan tinggi mata berbeda. Panjang mata $P$. duvaucelii berkembang lebih lambat terhadap panjang mantel, panjang kepala, dan panjang gladius serta berkembang lebih cepat terhadap panjang tentakel. Tinggi mata $P$. duvaucelii tumbuh seimbang terhadap panjang mata, berkembang lebih cepat terhadap panjang tentakel, dan berkembang lebih lambat terhadap panjang mantel dan panjang kepala. Cumi-cumi dapat bergerak sangat cepat, mempunyai mobilitas tinggi dan sistem penglihatan yang sangat baik, berhubungan dengan koordinasi otot lengan dan tentakel, keduanya dilengkapi dengan sucker atau pengait, membuat cumi-cumi sangat efisien dalam memburu (Jereb and Roper, 2010).

Panjang mata P.chinensis berkembang lebih lambat terhadap panjang mantel dan panjang kepala serta lebih cepat terhadap tinggi mata. Panjang mata berkembang seimbang terhadap panjang tentakel dan panjang gladius. Tinggi mata berkembang lebih lambat terhadap panjang mantel, panjang kepala, dan panjang gladius serta tumbuh seimbang terhadap panjang tentakel. Cumi-cumi telah mempunyai sistem yang berkembang untuk tetap fokus pada benda yang bergerak pada retina, ketika hewan bergerak oleh mata yang bergerak dikoordinasikan dengan kepala/badan yang kemudian ikut bergerak (Jereb and Roper, 2010).

Sirip pada cumi-cumi sebagai organisme predator merupakan bagian tubuh yang penting karena berfungsi untuk berenang dan mengejar mangsa (Jereb and Roper, 2010). Pertumbuhan panjang sirip pada P.duvaucelii lebih cepat dibandingkan bagian tubuh yang lain sedangkan pada $P$. chinensis, panjang sirip tumbuh lebih cepat dibandingkan bagian tubuh yang lain, dan seimbang terhadap pertumbuhan lebar sirip.

Pertumbuhan lebar sirip P.duvaucelii berbeda dengan P.chinensis. Lebar sirip P.duvaucelii tumbuh lebih lambat terhadap panjang mantel dan panjang sirip, serta tumbuh lebih cepat terhadap panjang tentakel. Pertumbuhan lebar sirip pada P.chinensis lebih cepat terhadap panjang tentakel dan seimbang terhadap pertumbuhan panjang sirip.

Berdasarkan uji Kolmogorov-Smirnov atas beberapa perbandingan variabel bagian tubuh dari cumicumi P.chinensis dan P.duvaucelii diketahui bahwa beberapa variabel morfometri dari kedua spesies tersebut memiliki sebaran tubuh yang berbeda nyata. Variabel morfometri atau bagian tubuh dari P.chinensis dan P.duvaucelii menunjukkan persamaan yang identik adalah dari bagian panjang tentakel. Hal ini dapat menunjukkan bahwa cumi-cumi P.chinensis dan P.duvaucelii yang tersebar di Pantai Utara Jawa Tengah memiliki perbedaan ukuran morfometri yang sangat signifikan.

Berdasarkan analisis Kolmogorov-smirnov tersebut maka untuk menguji pengelompokkan ukuran morfometri tersebut digunakan suatu indeks pengelompokkan dan dianalisis menggunakan uji Mann-Whitney. Uji ini digunakan untuk menguji populasi yang berbeda dan bersifat acak. Berdasarkan uji Mann-Whitney diatas maka dapat dilihat setiap indeks pengelompokkan memiliki perbedaan yang sangat nyata dari kedua spesies tersebut. Menurut Liao, et. al. (2010), karakter morfometri dari suatu organisme tidak berasal dari organisme itu 
sendiri tetapi berkoordinasi dengan berbagai aspek morfometri. Hal ini lebih tepat untuk menganalisis semua variabel morfometri dari populasi yang berbeda secara bersamaan ketika membandingkan karakter morfometri.

\section{Kesimpulan dan Saran}

Kesimpulan yang dapat diambil dari penelitian ini adalah karakteristik morfometri pertumbuhan panjang mantel kedua spesies lebih cepat dibanding organ tubuh lainnya dan masing-masing variabel organ tubuh mempunyai perbedaan yang nyata dan identik hanya pada panjang tentakel. Pola pertumbuhan dari kedua spesies yaitu pertambahan panjang pada P.chinensis lebih cepat dibanding P.duvaucelii dan bentuk tubuh dari kedua spesies cumi-cumi yaitu kurang pipih.

Saran

Adapun saran yang dapat diberikan adalah perlu adanya penelitian lanjutan tentang aspek biologi cumicumi seperti kematangan gonad dan penetasan telur. Agar ketika musim memijah dan matang gonad tidak dilakukan penangkapan pada cumi-cumi tersebut. Sehingga stok cumi-cumi yang diambil dari alam tidak melebihi batas maksimum sehingga mencegah terjadinya overfishing.

\section{Ucapan Terima Kasih}

Penulis mengucapkan terimakasih kepada Prof. Norma Afiati, M.Sc, Ph.D dan Dra. Niniek Widyorini, MS atas bimbingan dan arahan dalam penyusunan jurnal ini.

\section{Daftar Pustaka}

Afiati, N. 2005. Karakteristik Pertumbuhan Alometri Cangkang Kerang Darah Anadara Indica (L.) (Bivalvia:Arcidae). Jurnal Saintek Perikanan Vol.1, No. 2, 2005; 45-52

Boyle, P and Rodhouse, P. 2005. Cephalopods: Ecology and Fisheries. Blackwell Science Ltd. Australia. 109 p Carpenter E.K and Niem V.H., 1998. The Living Marine Resources of the Western Central Pacific. Volume 2. Cephalopods, Crustaceans, Holothurians and Shark. FAO Species Identification Guide for Fisheries Purpose, Rome, pp774-775.

Effendie, I. 2002. Biologi Perikanan.Yayasan Pustaka Nusatama.Bogor. 97 hlm.

Hadi, S. 2004. Metodologi Research. Andi offset. Yogyakarta. $336 \mathrm{hlm}$

Imron, M. 2008. Pemanfaatan Sumberdaya Perikanan Demersal yang Berkelanjutan di Perairan Tegal Jawa Tengah. [Disertasi] Institut Pertanian Bogor. Jawa Barat. 136-137 hal.

Jackson, G.D. 1991. Age, Growth and Population Dynamics of Tropical Squid and Sepioid Population in Waters off Townsville, North Queensland, Australia. [Thesis]. James Cook University. Autralia. 170p.

Jereb, P. and Roper, C.F.E, 2010. Cephalopods of The World. An Annotated and Illustrated Catalogue of Cephalopod Species Known to Date.Volume 2. Myopsid and Oegopsid Squids . FAO Species Catalogue for Fisheries Purpose no. 4, vol.2 106-108pp

Karnik, N.S and Chakraborty, S.K. 2001. Length-weight relationship and Morphometric Study on the Squid Loligo duvauceli (d' Orbigny) (Mollusca/Cephalopoda) off Mumbai (Bombay) waters, West Coast of India. Indian journal of Marine Sciences. Vol. 30(4), December 2001, pp.261-263

Liao, C.H., Liu.T.Y., Hung.C.Y.Morphometric Variation Between the Swordtip (Photololigo Edulis) And Mitre (P. Chinensis) Squids in the Waters Of Taiwan. Journal of Marine Science and Technology, Vol. 18, No. 3, pp. 405-412 (2010)

Mujiono, N. 2009. Spesimen Tipe Cephalopoda dari Perairan Indonesia. Oseana, Volume XXXIV, Nomor 4, Tahun $2009: 9-15$.

Nurdawati, S. 2010. Pola Pertumbuhan dan Faktor Kondisi Ikan Tilan (Mastacembelus erythrotaenia Bleeker 1850) sehubungan dengan Perubahan Musim dan Tipe Habitat di Sungai Musi Bagian Hilir. Sumatera Selatan. 29(2): 22-30

Safar, G., Saputra,I.A., Jayanti,A. Hermoza,T. 2007. Modul Metode Statistiksa. Universitas Gadjah Mada Yogyakarta. 56 hal

Sulistiono, M. 2001. Pertumbuhan Ikan Belanak (Mugil dussumieri) di Perairan Ujung Pangkah, Jawa Timur. Jurnal Ikhtiologi Indonesia. 1 (2) : 39-47

Suryana. 2010. Metodologi Penelitian. Buku Ajar Perkuliahan UPI. Tidak Diterbitkan

Sutanto, H.A.2005. Analisis Efesiensi Alat Tangkap Perikanan Gillnet dan Cantrang. [Tesis] Universitas Diponegoro. Semarang. 107 hal.

Tallo, I. 2006. Perbedaaan Jenis dan Kedalaman Pemasangan Atraktor Terhadap Penempelan Telur Cumi-Cumi [Tesis] Institut Pertanian Bogor. Bogor. 64 hal

Uyanto, S. 2009. Pedoman Analisis Data dengan SPSS. Graha Ilmu. Yogyakarta. 321 hal. 